\title{
Two Neolignan Glucosides and Antihistamine Release Activities from Bidens parviflora WILLD.
}

\author{
Nai Li WAnG, ${ }^{* a}$ Jue WAnG, ${ }^{b}$ Xin Sheng YaO, ${ }^{a}$ and Susumu KitANAKA ${ }^{*, b}$ \\ ${ }^{a}$ Department of Natural Products Chemistry, Shenyang Pharmaceutical University; 103 Wenhua Road, Shenhe District, \\ Shenyang, Shenyang 110015, China: and ${ }^{b}$ College of Pharmacy, Nihon University; 7-7-1 Narashinodai, Funabashi, \\ Chiba 274-8555, Japan. Received December 9, 2005; accepted March 31, 2006
}

Two new neolignan glucosides, bidenlignasides A (1) and B (2), were isolated from the whole plant of Bidens parviflora WILLD. The structures of the two new compounds 1 and 2 established to be 3-hydroxy-1-(4-hydroxy-3methoxyphenyl)-3-[5E-(3-hydroxypropenyl)-3-methoxy-2- $O$ - $\beta$-D-glucosyl)phenyl] propan-1-one and 3-\{3-[1,3-dihydroxy-3-(4-hydroxy-3-methoxyphenyl)propyl]-4-hydroxy-5-methoxyphenyl\}-allyl- $O$ - $\beta$-D-glucuside, respectively, on the basis of spectral and chemical evidence. Compounds 1 and 2 were found to inhibit histamine release from peritoneal exudate mast cells induced by antigen-antibody reaction.

Key words Bidens parviflora; bidenlignaside A; bidenlignaside B; antiallergic agent; histamine release inhibitor

In our bioactivity screening of Compositae plants, the extract of Bidens parviflora WILLD. has been shown to have high activity against histamine release from rat mast cells induced by compound 48/80. In previously studies, sterols, ${ }^{1)}$ flavonones, ${ }^{2)}$ flavonoids, ${ }^{3)}$ polyacetylene glucosides, ${ }^{4)}$ chalcones, ${ }^{5,6)}$ aurones, ${ }^{7)}$ and flavonol glycosides ${ }^{8)}$ were isolated from the Bidens family. For the purpose of finding biological active compounds, the chemical constituents of this plant have been extensively studied. During our previous studies, it was reported that five polyacetylene glucosides ${ }^{9)}$ and three sucrose coumaroylesters were thought to contribute to the inhibition of histamine release. ${ }^{11)}$ In this paper, we report the isolation and structural elucidation of two new neolignan glycosides, bidenlignasides A (1) and B (2). The extraction and separation were carried out as described in Experimental.

Bidenlignaside A (1) was obtained as a colorless powder $(\mathrm{MeOH}) ;[\alpha]_{\mathrm{D}}^{25}-16.5^{\circ}$. Its molecular formula $\mathrm{C}_{26} \mathrm{H}_{32} \mathrm{O}_{12}$ was deduced from the FAB-MS, $m / z 537(\mathrm{M}+\mathrm{H})^{+}$; high-resolution positive-ion FAB-MS Calcd for $\mathrm{C}_{26} \mathrm{H}_{33} \mathrm{O}_{12}\left([\mathrm{M}+\mathrm{H}]^{+}\right)$: 537.19712; Found: 537.19659. The IR spectrum of 1 showed absorption bands at 3395, 2932, 1662, 1587, 1462, and $1423 \mathrm{~cm}^{-1}$ ascribable to hydroxyl, carboxyl, aromatic ring, and ether functions. In the UV spectrum of 1 , absorption maxima were observed at $248(\log \varepsilon 3.95)$ and $267(\log \varepsilon$ 4.04) nm, which suggest a phenol structure. The $1 \mathrm{D}{ }^{1} \mathrm{H}-$ NMR spectrum of $\mathbf{1}$ and $2 \mathrm{D}{ }^{1} \mathrm{H}-{ }^{1} \mathrm{H}$ COSY spectra showed the presence of a 1,3,4-trisubstituted benzene ring (ring A) $[\delta$ $7.68(1 \mathrm{H}, \mathrm{d}, J=2.1 \mathrm{~Hz}, \mathrm{H}-2), \delta 6.79(1 \mathrm{H}, \mathrm{d}, J=8.3 \mathrm{~Hz}, \mathrm{H}-5)$, and $\delta 7.69(1 \mathrm{H}, \mathrm{dd}, J=8.3,2.1 \mathrm{~Hz}, \mathrm{H}-6)]$, a $1,3^{\prime}, 4^{\prime}, 5^{\prime}$-tetrasubstituted benzene ring (ring B) $[\delta 6.98(1 \mathrm{H}, \mathrm{d}, J=1.9 \mathrm{~Hz}$, $\mathrm{H}-2), \delta 6.72(1 \mathrm{H}, \mathrm{d}, J=1.9 \mathrm{~Hz}, \mathrm{H}-6)]$, an oxygen-bearing methine $[\delta 5.52(1 \mathrm{H}, \mathrm{dd}, J=9.2,3.5 \mathrm{~Hz}, \mathrm{H}-9)]$ and a methylene $[\delta 4.36(1 \mathrm{H}, \mathrm{dd}, J=10.4,9.2 \mathrm{~Hz}, \mathrm{H}-8 \mathrm{a}), \delta 3.74(1 \mathrm{H}, \mathrm{dd}$, $J=10.4,3.5 \mathrm{~Hz}, \mathrm{H}-8 \mathrm{~b})]$, and a hydroxy propylene group $[\delta$ $6.47(1 \mathrm{H}, \mathrm{d}, J=15.9 \mathrm{~Hz}, \mathrm{H}-7), \delta 6.25(1 \mathrm{H}, \mathrm{dt}, J=15.9$, $5.5 \mathrm{~Hz}, \mathrm{H}-8)$ and $\delta 4.17(2 \mathrm{H}, \mathrm{dd}, J=5.5,1.5 \mathrm{~Hz}, \mathrm{H}-9)]$, in addition to two methoxyl groups $[\delta 3.90(3 \mathrm{H}, \mathrm{s}, \mathrm{C}-3), \delta 3.88$ $(3 \mathrm{H}, \mathrm{s}, \mathrm{C}-3)] .{ }^{1} \mathrm{H}-$ and ${ }^{13} \mathrm{C}-\mathrm{NMR}$ spectra (Table 1$)$ indicated the presence of a $\beta$-D-glucosyl moiety at $\delta 4.92(1 \mathrm{H}, \mathrm{d}$, $J=7.6 \mathrm{~Hz}$, glc-H-1), $\delta_{\mathrm{C}} 105.9$ (glc-C-1), 78.5 (glc-C-5), 78.0 (glc-C-3), 76.1 (glc-C-2), 70.9 (glc-C-4), and 62.3 (glc-C-6). Acid hydrolysis of 1 with $5 \%$ sulfuric acid $\left(\mathrm{H}_{2} \mathrm{SO}_{4}\right)$ furnished D-glucose, which was identified by gas-liquid chromatography (GLC) analysis of the trimethylsilyl (TMS) thiazolidine derivative. ${ }^{11)}$ In its ${ }^{13} \mathrm{C}$-NMR spectrum, except for the signals due to the glucose, the remaining carbon signals consisted of a carbonyl group $\left(\delta_{\mathrm{C}} 199.3, \mathrm{C}-7\right)$, an oxygen-bearing methine $\left(\delta_{\mathrm{C}} 64.5, \mathrm{C}-9\right)$, a methylene $\left(\delta_{\mathrm{C}} 49.3, \mathrm{C}-8\right)$, a hydroxy propylene group $\left(\delta_{\mathrm{C}} 130.8, \mathrm{C}-7, \delta_{\mathrm{C}} 130.6, \mathrm{C}-8, \delta_{\mathrm{C}} 63.6, \mathrm{C}-\right.$ $9)$, and two aromatic rings. The HMBC correlations between the $\delta_{\mathrm{C}} 143.6(\mathrm{C}-4)$ and $\delta_{\mathrm{H}} 4.92(\mathrm{glc}-\mathrm{H}-1)$ suggested that the glucopyranosyl moiety was attached at the $\mathrm{C}-4$ of ring $\mathrm{B}$. HMBC correlations were observed between $\mathrm{H}-2$ and $\mathrm{H}-6 / \mathrm{C}-7$ and between $\mathrm{H}-2$ and $\mathrm{H}-6 / \mathrm{C}-7$. These results indicate that 1 has two phenylpropanoid units. Significant correlations were also observed between $\mathrm{H}-8 / \mathrm{C}-1$ and $\mathrm{C}-5$ and between $\mathrm{H}-9 / \mathrm{C}-$
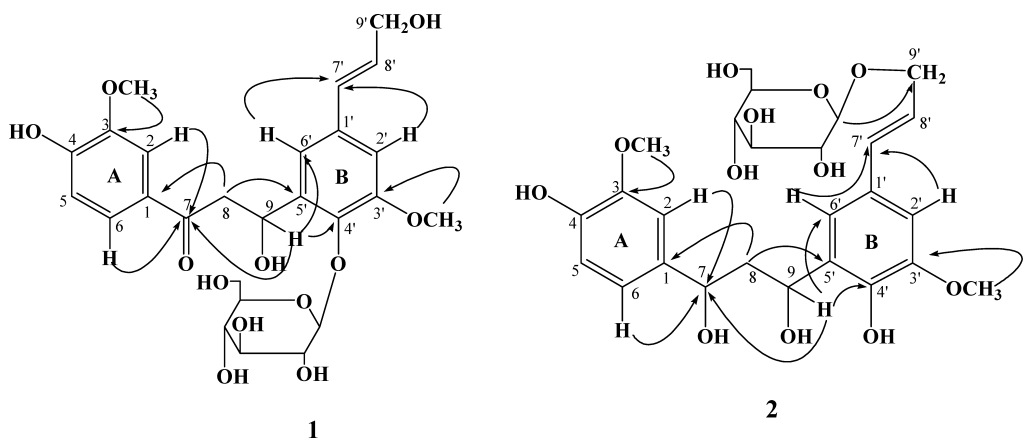

Fig. 1. HMBC Correlations of $\mathbf{1}$ and $\mathbf{2}$ 
7 and C-4, C-6. The position of the methoxyl group was determined to at $\mathrm{C}-3$ and $\mathrm{C}-3$ based on NOESY $\left(3-\mathrm{OCH}_{3} / \mathrm{H}-2\right.$, $\left.3-\mathrm{OCH}_{3} / \mathrm{H}-2\right)$ and $\mathrm{HMBC}$ experiments $\left(3-\mathrm{OCH}_{3} / \mathrm{C}-3,3-\right.$ $\left.\mathrm{OCH}_{3} / \mathrm{C}-3\right)$. The structure of 1 was elucidated to be 3 -hydroxy-1-(4-hydroxy-3-methoxyphenyl)-3-[5E-(3-hydroxyprop-1-enyl)-3-methoxy-2-O- $\beta$-D-glucosyl)-phenyl]propan-1-one, which was designated bidenlignaside $\mathrm{A}$.

Bidenlignaside B (2) was also obtained as a colorless powder $(\mathrm{MeOH}) ;[\alpha]_{\mathrm{D}}^{25}-18.2^{\circ}$. Its molecular formula $\mathrm{C}_{26} \mathrm{H}_{34} \mathrm{O}_{12}$ was deduced from the FAB-MS, $m / z 537(\mathrm{M}-\mathrm{H})^{+}$; high-resolution positive-ion FAB-MS Calcd for $\mathrm{C}_{26} \mathrm{H}_{33} \mathrm{O}_{12}([\mathrm{M}-$ $\mathrm{H}^{+}$): 537.19712; Found: 537.19700. The IR spectrum of 2 showed absorption bands at 3412, 2931, 1715, 1604, 1512, 1482,1422 , and $1369 \mathrm{~cm}^{-1}$ ascribable to hydroxyl, aromatic ring and ether functions. In the UV spectrum of 2, absorption maxima were observed at $246(\log \varepsilon$ 4.45) and $268(\log \varepsilon$ $3.02) \mathrm{nm}$, which suggest a phenol structure. The $1 \mathrm{D}$ NMR spectrum of 2 and 2D NMR spectra also showed the presence of a 1,3,4-trisubstituted benzene ring (ring A) and a 1,3,4,5-tetrasubstituted benzene ring (ring $\mathrm{B}$ ). ${ }^{1} \mathrm{H}$ - and ${ }^{13} \mathrm{C}$ NMR spectra (Table 1) indicated the presence of a $\beta$-D-glucosyl moiety. Acid hydrolysis of 2 with $5 \%$ sulfuric acid $\left(\mathrm{H}_{2} \mathrm{SO}_{4}\right)$ furnished D-glucunic acid, which was identified by GLC analysis of the TMS thiazolidine derivative. ${ }^{11)}$ In its ${ }^{13} \mathrm{C}$-NMR spectrum, except for the signals due to glucose, the remaining carbon signals consisted of two oxygen-bearing methines $\left(\delta_{\mathrm{C}} 74.2, \mathrm{C}-7, \delta_{\mathrm{C}} 62.3, \mathrm{C}-9\right)$, a methylene $\left(\delta_{\mathrm{C}}\right.$ $46.3, \mathrm{C}-8)$, a hydroxy propylene group $\left[\delta_{\mathrm{C}} 134.4,(\mathrm{C}-7)\right.$,

Table $1 .{ }^{13} \mathrm{C}$ - and ${ }^{1} \mathrm{H}$-NMR Data of Compounds $\mathbf{1}$ and $\mathbf{2}$

\begin{tabular}{|c|c|c|c|c|}
\hline \multirow{2}{*}{ Aglycone } & \multicolumn{2}{|r|}{1} & \multicolumn{2}{|r|}{2} \\
\hline & $\delta_{\mathrm{C}}$ & $\delta_{\mathrm{H}}$ & $\delta_{\mathrm{C}}$ & $\delta_{\mathrm{H}}$ \\
\hline 1 & $130.2 \mathrm{~s}$ & & $134.1 \mathrm{~s}$ & \\
\hline 2 & $112.8 \mathrm{~d}$ & $7.68 \mathrm{~d}(2.1)$ & $111.9 \mathrm{~d}$ & $7.01 \mathrm{~d}(2.1)$ \\
\hline 3 & $148.8 \mathrm{~s}$ & & $148.7 \mathrm{~s}$ & \\
\hline 4 & $153.2 \mathrm{~s}$ & & $147.1 \mathrm{~s}$ & \\
\hline 5 & $115.9 \mathrm{~d}$ & $6.79 \mathrm{~d}(8.3)$ & $115.7 \mathrm{~d}$ & $6.72 \mathrm{~d}(8.3)$ \\
\hline 6 & $124.9 \mathrm{~d}$ & $7.69 \mathrm{dd}(8.3,2.1)$ & $121.1 \mathrm{~d}$ & $6.82 \mathrm{dd}(8.3,2.1)$ \\
\hline 7 & $199.3 \mathrm{~s}$ & & $74.2 \mathrm{~d}$ & $4.83 \mathrm{dd}(5.8,3.2)$ \\
\hline \multirow[t]{2}{*}{8} & $49.3 \mathrm{t}$ & $4.36 \mathrm{dd}(10.4,9.2)$ & $46.3 \mathrm{t}$ & $3.80 \mathrm{dt}(9.6,5.8)$ \\
\hline & & $3.74 \mathrm{dd}(10.4,3.5)$ & & $3.67 \mathrm{dt}(9.6,3.2)$ \\
\hline 9 & $64.5 \mathrm{~d}$ & $5.52 \mathrm{dd}(9.2,3.5)$ & $62.3 \mathrm{~d}$ & $4.37 \mathrm{dd}(5.8,3.2)$ \\
\hline $3-\mathrm{OCH}_{3}$ & $56.6 \mathrm{q}$ & $3.90 \mathrm{~s}$ & $56.6 \mathrm{q}$ & $3.76 \mathrm{~s}$ \\
\hline $1^{\prime}$ & $136.1 \mathrm{~s}$ & & $132.8 \mathrm{~s}$ & \\
\hline $2^{\prime}$ & $118.8 \mathrm{~d}$ & $6.98 \mathrm{~d}(1.9)$ & $120.9 \mathrm{~d}$ & $6.87 \mathrm{~d}(1.9)$ \\
\hline $3^{\prime}$ & $133.6 \mathrm{~s}$ & & $139.2 \mathrm{~s}$ & \\
\hline $4^{\prime}$ & $143.6 \mathrm{~s}$ & & $149.2 \mathrm{~s}$ & \\
\hline $5^{\prime}$ & $154.0 \mathrm{~s}$ & & $151.9 \mathrm{~s}$ & \\
\hline $6^{\prime}$ & $110.4 \mathrm{~d}$ & $6.72 \mathrm{~d}(1.9)$ & $111.5 \mathrm{~d}$ & $7.01 \mathrm{~d}(1.9)$ \\
\hline $7^{\prime}$ & $130.8 \mathrm{~d}$ & $6.47 \mathrm{~d}(15.9)$ & $134.4 \mathrm{~d}$ & $6.58 \mathrm{~d}(15.9)$ \\
\hline $8^{\prime}$ & $130.6 \mathrm{~d}$ & $6.25 \mathrm{dt}(15.9,5.5)$ & $125.2 \mathrm{~d}$ & $6.23 \mathrm{dt}(15.9,6.4)$ \\
\hline \multirow[t]{2}{*}{$9^{\prime}$} & $63.6 \mathrm{t}$ & $4.17 \mathrm{dd}(5.5,1.5)$ & $70.9 \mathrm{t}$ & $4.49 \mathrm{dd}(12.5,6.4)$ \\
\hline & & & & $3.88 \mathrm{dd}(12.5,6.4)$ \\
\hline $3^{\prime}-\mathrm{OCH}_{3}$ & $56.5 \mathrm{q}$ & $3.88 \mathrm{~s}$ & $56.4 \mathrm{q}$ & $3.79 \mathrm{~s}$ \\
\hline \multicolumn{5}{|l|}{ Glucose } \\
\hline 1 & $105.9 \mathrm{~d}$ & $4.92 \mathrm{~d}(7.6)$ & $103.3 \mathrm{~d}$ & $4.35 \mathrm{~d}(7.6)$ \\
\hline 2 & $76.1 \mathrm{~d}$ & $3.22 \mathrm{~m}$ & $75.2 \mathrm{~d}$ & $3.20 \mathrm{~m}$ \\
\hline 3 & $78.0 \mathrm{~d}$ & $3.49 \mathrm{dm}$ & $78.0 \mathrm{~d}$ & $3.36 \mathrm{~m}$ \\
\hline 4 & $70.9 \mathrm{~d}$ & $3.49 \mathrm{~m}$ & $71.7 \mathrm{~d}$ & $3.28 \mathrm{~m}$ \\
\hline 5 & $78.5 \mathrm{~d}$ & $3.26 \mathrm{~m}$ & $78.2 \mathrm{~d}$ & $3.26 \mathrm{~m}$ \\
\hline \multirow[t]{2}{*}{6} & $62.3 \mathrm{t}$ & $3.85 \mathrm{dd}$ & $62.7 \mathrm{t}$ & $3.84 \mathrm{dd}$ \\
\hline & & $3.78 \mathrm{dd}$ & & $3.76 \mathrm{dd}$ \\
\hline
\end{tabular}

Assigned by the ${ }^{1} \mathrm{H}-{ }^{1} \mathrm{H}$ COSY, HMQC, and HMBC spectra. $125 \mathrm{MHz}$ to ${ }^{13} \mathrm{C}-$ NMR, $500 \mathrm{MHz}$ to ${ }^{1} \mathrm{H}-\mathrm{NMR}$, TMS as int. standard (ppm, in $\left.\mathrm{MeOH}-d_{4}\right)$.
125.2, (C-8), 70.9, (C-9)], and two aromatic rings. The HMBC correlations between $\delta_{\mathrm{C}} 7.09(\mathrm{C}-9)$ and $\delta_{\mathrm{H}} 4.35$ (glc$\mathrm{H}-1)$ suggested that the glucospyranosyl moiety was attached at the $\mathrm{C}-9$ of the hydroxy propylene group in ring B. Correlations were observed between $\mathrm{H}-2$ and $\mathrm{H}-6 / \mathrm{C}-7$ and between $\mathrm{H}-2$ and $\mathrm{H}-6 / \mathrm{C}-7$. These results indicate that 2 has two phenylpropanoid units. The most significant HMBC correlations were observed between $\mathrm{H}-8 / \mathrm{C}-1$ and $\mathrm{C}-5$ and between $\mathrm{H}-9 / \mathrm{C}-7$ and $\mathrm{C}-4, \mathrm{C}-6$. The position of the methoxyl group was determined to be at $\mathrm{C}-3$ and $\mathrm{C}-3$ based on NOESY $\left(-\mathrm{OCH}_{3} / \mathrm{H}-2,-\mathrm{OCH}_{3} / \mathrm{H}-2\right)$ and $\mathrm{HMBC}$ correlations $\left(-\mathrm{OCH}_{3} /\right.$ $\left.\mathrm{C}-3,-\mathrm{OCH}_{3} / \mathrm{C}-3\right)$. The structure of 2 was elucidated to be 3\{3-[1,3-dihydroxy-3-(4-hydroxy-3-methoxyphenyl)-propyl]4-hydroxy-5-methoxyphenyl $\}$ allyl- $O$ - $\beta$-D-glucoside and we designated it bidenlignaside $\mathrm{B}$.

It has been noted that the stereochemistry at C-9 for $\mathbf{1}$, and at C-7 and C-9 for 2, has not been confirmed. We examined the inhibitory activity of bidenlignaside A (1) and bidenlignaside B (2) on histamine release from rat peritoneal exudate cells induced by antigen-antibody reaction. The inhibitory effects of $1\left(\mathrm{IC}_{50}, 25.1 \mu \mathrm{g}\right)$ and $\mathbf{2}\left(\mathrm{IC}_{50}, 37.2 \mu \mathrm{g}\right)$ had the same activity as the potent antiinflammatory drug, indomethacin $\left(\mathrm{IC}_{50}, 24.3 \mu \mathrm{M}\right)$. These results suggest that bidenlignaside $\mathrm{A}$ and bidenlignaside $\mathrm{B}$ have prospects in the further development of antiallergic drugs and therapy of related diseases.

\section{Experimental}

General Experimental Procedures All the melting points were determined on a Yanagimoto micro-melting-point apparatus and are uncorrected The UV spectrum was obtained on a Hitachi 200-10 spectrophotometer, and the IR spectrum was recorded on a JASCO IR A-2 spectrophtometer. The ${ }^{1} \mathrm{H}$ - and ${ }^{13} \mathrm{C}$-NMR spectra were recorded on JEOL GL-500 and JEOL FX100 spectrometers, respectively, using TMS as an internal standard. The MS were obtained on a Hitachi M-80B spectrometer. Column chromatography was carried out with silica gel (Wako gel C-300, Wako Pure Chemical Industry Ltd.) and Sephadex LH-20 (20-100 mm, Pharmacia Fine Chemical Co., Ltd.). Thin-layer chromatography (TLC) was performed on SigmaAldrich TLC plates $(250 \mu \mathrm{m}$ thickness), with compounds visualized by spraying with $5 \%(\mathrm{v} / \mathrm{v}) \mathrm{H}_{2} \mathrm{SO}_{4}$ in ethanol solution.

Plant Materials The whole plant of $B$. parviflora WILLD. was collected from Liaoning province (China) and was identified by Prof. Weichun Wu (Department of Medical Plants, Shenyang Pharmaceutical University, China). A voucher specimen is deposited at the Department of Natural Products Chemistry, Shenyang Pharmaceutical University.

Extraction and Isolation The air-dried whole plant $(5.5 \mathrm{~kg})$ was extracted twice with $60 \%$ ethanol under reflux. Evaporation of the solvent under reduced pressure from the combined extract gave the $60 \% \mathrm{EtOH}$ extract $(674.2 \mathrm{~g})$. The extract was dissolved and suspended in water (2.01) and partitioned with hexane $(3 \times 21)$, ethyl acetate $(3 \times 21)$ and $n$-butanol $(3 \times 21)$, respectively, and then solvents were evaporated to yield the hexane extract $(136 \mathrm{~g})$, ethyl acetate extract $(126 \mathrm{~g})$, butanol extract $(176 \mathrm{~g})$, and aqueous extract ( $376 \mathrm{~g})$. The butanol extract was subjected to silica gel column chromatography $\left(\mathrm{SiO}_{2}, 400 \mathrm{~g}\right.$; eluted with $\mathrm{CHCl}_{3}$ and $\mathrm{MeOH}$ in increasing polarity to obtain nine fractions. Fr. 7 was subjected to Sephadex LH-20 column chromatography eluted with $50 \% \mathrm{MeOH}$ to obtain fr. $7-8$ and was purified by preparative HPLC (Sunshu Park, Pegasil ODS, 35\% MeOH) to give $14 \mathrm{mg}$ of compound $\mathbf{1}$ and $12 \mathrm{mg}$ of compound $\mathbf{2}$.

Bidenlignaside A (1): Colorless powder $(\mathrm{MeOH}) ;[\alpha]_{\mathrm{D}}^{25}-16.5^{\circ}(c=0.14)$. UV (methanol) $\lambda_{\max }(\log \varepsilon): 222$ (4.34), 248 (3.95), 267 (4.04). IR $v_{\max }$ $\mathrm{cm}^{-1}: 3395,2932,1662,1587,1462,1423,1273,1232$. FAB-MS, $m / z 537$ $(\mathrm{M}+\mathrm{H})^{+}, 163$ (100); high-resolution positive-ion FAB-MS Calcd for $\mathrm{C}_{26} \mathrm{H}_{33} \mathrm{O}_{12}(\mathrm{M}+\mathrm{H})^{+}:$537.19712; Found: 537.19659. ${ }^{1} \mathrm{H}-$ and ${ }^{13} \mathrm{C}-\mathrm{NMR}$ spectral data (in MeOH- $d_{4} ; 500 \mathrm{MHz}$ and $125 \mathrm{MHz}$; see Table 1).

Bidenlignaside $\mathrm{B}(\mathbf{2})$ : Colorless powder $(\mathrm{MeOH}) ;[\alpha]_{\mathrm{D}}^{25}-18.2^{\circ}(c=0.31)$ UV (methanol) $\lambda_{\max }(\log \varepsilon): 207$ (4.39), 246 (4.45), 268 (2.09). IR $v_{\max }$ $\mathrm{cm}^{-1}: 3412,2931,1715,1604,1512,1482,1422,1369$. FAB-MS, $m / z 537$ $(\mathrm{M}+\mathrm{H})^{-}, 163(100)$; high-resolution negative-ion FAB-MS Calcd for $\mathrm{C}_{26} \mathrm{H}_{34} \mathrm{O}_{12}(\mathrm{M}+\mathrm{H})^{-}: 537.19712$; Found: 537.19700. ${ }^{1} \mathrm{H}$ - and ${ }^{13} \mathrm{C}-\mathrm{NMR}$ spec- 
tral data (in $\mathrm{MeOH}-d_{4} ; 500 \mathrm{MHz}$ and $125 \mathrm{MHz}$; see Table 1).

Acid Hydrolysis of 1 and 2 A solution of 1 and 2 ( $2 \mathrm{mg}$ each) in 5\% aqueous $\mathrm{H}_{2} \mathrm{SO}_{4}-1$,4-dioxane $(0.5 \mathrm{ml}, 1: 1, \mathrm{v} / \mathrm{v})$ was heated under reflux for $1 \mathrm{~h}$. After cooling, the reaction mixture was neutralized with Amberlite IRA$400\left(\mathrm{OH}^{-}\right.$form $)$and the residue was removed by filtration. After solvent was removed from the filtrate in vacuo, the residue was transferred to a SepPak $\mathrm{C} 18$ cartridge with $\mathrm{H}_{2} \mathrm{O}$ and $\mathrm{MeOH}$. The $\mathrm{H}_{2} \mathrm{O}$ eluate was concentrated and the residue was treated with L-cysteine methyl ester hydrochloride $(4 \mathrm{mg})$ in pyridine $(0.5 \mathrm{ml})$ at $60^{\circ} \mathrm{C}$ for $1 \mathrm{~h}$. After reaction, the solution was treated with $\mathrm{N}, \mathrm{O}$-bis(trimethysily)trifluoroacetamide $(0.2 \mathrm{ml})$ at $60^{\circ} \mathrm{C}$ for $1 \mathrm{~h}$. The supernatant was then subjected to GLC analysis to identify the derivatives of D-glucose. GLC conditions: Supeluco STM-1, $30 \mathrm{~m} \times 0.25 \mathrm{~mm}$ (i.d.) capillary column; injector temperature, $230{ }^{\circ} \mathrm{C}$, detector $230{ }^{\circ} \mathrm{C}$; column temperature, $230^{\circ} \mathrm{C}$; He gas flow rate, $15 \mathrm{ml} / \mathrm{min}$; and $t_{\mathrm{R}}, 24.5 \mathrm{~min}$ (from 1 and 2 ).

Histamine Release Assay The isolated compounds font assayed using the HPLC-fluorometry method previously described ${ }^{12)}$ with modifications. Male Wistar rats (Japan SLC, Shizuoka) weighing 180 - 200 g were exsanguinated and injected intraperitoneally with $10 \mathrm{ml}$ of tyrode solution. The abdominal region was gently massaged for $3 \mathrm{~min}$ and then the peritoneal exudates were collected. The peritoneal cavity fluid containing mast cells was suspended in PBS, then layered on BSA $(d=1.068)$ in a test tube at room temperature for $20 \mathrm{~min}$. After centrifugation at $300 \times \mathbf{g}$ and $4{ }^{\circ} \mathrm{C}$ for $10 \mathrm{~min}$, the layer containing mast cells was pipetted out. The cells were washed three times with $3 \mathrm{ml}$ of PBS ( $\mathrm{pH} \mathrm{7.0)}$ ) and suspended in the same medium. Cell viability was determined using trypan blue. Mast cells $\left(1 \times 10^{6}\right.$ cells $\left./ \mathrm{ml}\right)$ were preincubated with test samples $(10 \mu \mathrm{l})$ at $37^{\circ} \mathrm{C}$ for $10 \mathrm{~min}$, followed by addition of histamine releasers, either compound $48 / 80(5 \mu \mathrm{g} / \mathrm{ml})$ or antiDNP-IgE $(5 \mu \mathrm{g} / \mathrm{ml})$ and phosphatidyl serine $(100 \mu \mathrm{g} / \mathrm{ml})$. The mixtures were incubated again for $10 \mathrm{~min}$, the quantity of histamine released was expressed in peak height, and the percentage inhibition was calculated.
Acknowledgements This work was financially supported in part by a Grant-in Aid for Scientific Research (No. 40102553) from the Ministry of Education, Culture, Sports, Science and Technology of Japan, by a Special Research Grant-in-Aid for the development of characteristic education and High-Tech Research Center from the Japanese Ministry of Education, and Science Sport and Culture to Nihon University and by the Japan-China Medical Association.

\section{References}

1) Chen A. H., Lin S. R., Hong C. H., Chem. Abstr., 84, 176691 (1976)

2) Hoffman B., Hozel J., Planta Med., 54, 450-451 (1988).

3) Hoffman B., Hozel J., Phytochemistry, 27, 3700-3704 (1988).

4) Bauer R., Redl K., Davis B., Phytochemistry, 31, 2035-2037 (1992).

5) Redl K., Davis B., Bauer R., Phytochemistry, 32, 218-220 (1993).

6) Hoffman B., Hozel J., Phytochemistry, 28, 247-247 (1989).

7) Sashida Y., Ogawa K., Kitada M., Karikome H., Mimaki Y., Shimomura H., Chem. Pharm. Bull., 39, 709-711 (1991).

8) De Tommasi N., Piacente S., Pizza C., J. Nat. Prod., 61, 973-977 (1998).

9) Wang N., Yao X., Ishii R., Kitanaka S., Chem. Pharm. Bull., 49, 938942 (2001).

10) Wang N., Yao X., Ishii R., Kitanaka S., Phytochemistry, 62, 741-746 (2003).

11) Hara S., Okabe H., Mihashi K., Chem. Pharm. Bull., 34, 1843-1845 (1986).

12) Kitanaka S., Nakayama T., Shibano T., Ohkoshi E., Takido M., Chem. Pharm. Bull., 46, 1650-1652 (1998). 